\title{
Secondary School Students' Mastery of Integrated Science Process Skills in Siaya County, Kenya
}

\author{
Richard Owino Ongowo \\ Department of Curriculum Instruction and Media, Rongo University, Rongo, Kenya \\ Email: ongoworichard@gmail.com,r_owino@yahoo.com
}

How to cite this paper: Ongowo, R. O. (2017). Secondary School Students' Mastery of Integrated Science Process Skills in Siaya County, Kenya. Creative Education, 8 , 1941-1956.

https://doi.org/10.4236/ce.2017.812132

Received: August 4, 2017

Accepted: September 25, 2017

Published: September 28, 2017

Copyright $\odot 2017$ by author and Scientific Research Publishing Inc. This work is licensed under the Creative Commons Attribution International License (CC BY 4.0).

http://creativecommons.org/licenses/by/4.0/

\begin{abstract}
The study investigated secondary school students' mastery of Integrated Science Process Skills (ISPS) among co-educational schools and the influence of grade level, gender, and school location in Siaya County, Kenya. The study used a causal-comparative design with purposive sampling technique. A 30-item Test of Integrated Science Process Skill (TISPS) developed by Kazeni (2005) was administered. The instrument assesses the skills of controlling variables, defining operationally, formulating hypotheses, experimenting and interpreting data. The instrument was administered to 429 students, 117, 108, 101 and 103 in grades $9,10,11$ and 12 respectively drawn from one urban co-educational school $(\mathrm{n}=215)$ and one rural co-educational school $(\mathrm{n}=$ 214). The data were analyzed by grade level using one-way ANOVA and by gender and school location using an independent sample t-test. The findings indicated moderate mastery of ISPS and statistically significant grade level differences between grades 9 and 10,10 and 11, 11 and 12, 9 and 11, 9 and 12, and 10 and 12; Gender differences in favor of boys and school location differences in favor of urban school students in mastery of ISPS. The following conclusions are made with regard to integrated science process skills: Mastery of ISPS increases with grade level; boys have a higher mastery of ISPS than girls; the urban school has a higher mastery of ISPS than the rural school. Implications for practice and further research are herein explicated.
\end{abstract}

\section{Keywords}

Mastery, Integrated Science Process Skills, Grade, Gender, School Location

\section{Introduction}

Science education is currently undergoing transformational changes throughout 
the globe and one of these is a pedagogical shift from the transmissionist philosophy of teaching to one where the learners are actively constructing scientific knowledge. Most of the contemporary science education curricula recognize science process skills as important component tools in the construction of scientific knowledge and conceptual change. According to Burns, Okey and Wise (1985), this became more prominent with the advent of several activity and discovery-oriented curricula such as Biological Sciences Curriculum Study (BSCS), Science Curriculum Improvement Study (SCIS), School Science Curriculum Project (SSCP) and Science A Process Approach (SAPA). These curricula emphasized the fact that science is a process in which the learners need to be part of and that if learners are to become scientists, they have to develop these abilities reflective of the behavior of scientists. These curricula also recognized that scientific knowledge had two domains: content knowledge (what scientists have found out) and process skills (what they do to find out). Concepts, explanations, understanding and theories constitute the content of science whereas science process skills refer to the rational and logical thinking skills used in science (Burns, Okey, \& Wise, 1985; Necati, 2013; Mutlu \& Temiz, 2013). According to Nwosu and Okeke (1995), science process skills are mental and physical abilities and competencies which serve as tools needed for the effective study of science and technology as well as problem solving and individual societal development. According to Ozgelen (2012), science process skills are thinking skills that scientists use to construct knowledge in order to solve problems and formulate results. The implication is that science process skills are inseparable from the practice of science and play a key role in both formal and informal learning of science content. They are important tools for producing and arranging information about the world around us based on prior knowledge.

According to Sukarno, Permanasari, and Ida (2013), science process skills and mastery of science concepts are inextricably intertwined, interrelated and mutually reinforcing. Jack (2013) opines that using science process skills is an indicator of transfer of knowledge that is needed for problem solving and functional living. Opateye (2012) observes that science process skills affect personal, social and global lives of individuals. Science process skills have been broadly categorized into two viz.: basic and integrated science process skills (Padilla, 1990; Keil, Haney, \& Zoffel, 2009; Aziz \& Zain, 2010). The basic science process skills are observation, classification, prediction, inferring, communicating and measuring. The basic process skills are foundational tools for construction of new knowledge. The integrated science process skills are controlling variables, defining operationally, formulating hypotheses, interpreting data, experimenting and formulating models.

\subsection{Literature Review on Integrated Science Process Skills}

The integrated science process skills are the terminal skills for solving problems or doing science experiments. The integrated science process skills are science 
process skills that incorporate or involve the use of different basic science process skills (Rambuda \& Fraser, 2004; Aziz \& Zain, 2010; Ozgelen, 2012; Mutlu \& Temiz, 2013). They are higher level cognitive skills (Aydin, 2013). The basic science process skills are not separate and distinct from integrated science process skills but provide the foundation or advancement to the more complex integrated skills (Rambuda \& Fraser, 2004). According to Keil, Haney and Zoffel (2009), integrated science process skills are needed to be scientifically literate; which is the ability to grasp essential science concepts, to understand the nature of science, to realize the relevance of science and technology in their lives and to willingly continue their science study in school or beyond school. Brotherton and Preece (1995) found out that there exists a strong correlation $(r=0.73)$ between integrated science process skills and formal thinking abilities. According to Aydin (2013), there is a shift to training students in a way that enables them to access knowledge, to distinguish what knowledge is necessary and to generate new knowledge on the basis of the knowledge they have accessed. In the view of Koray et al. (cited in Aydin, 2013), this shift is only possible through the mastery and acquisition of integrated science process skills.

According to Padilla (1990), students cannot excel at skills they have not experienced or allowed to practice. Mastery of integrated science process skills can only occur after consistent practical sessions. This will allow for the development of formal thinking patterns. Padilla (1990) continues to aver that students need multiple opportunities to work with these skills in different content and context areas. In this regard science education teachers need to help the learners to develop formal thinking patterns for them to successfully master integrated science process skills. Feyzioglu (2009) investigated whether there exists a correlation between science process skills and efficient laboratory use among university students. The findings indicated that a positively significant linear relationship exists between high-level (integrated) science process skills taught in laboratory applications and science achievement $(r=0.746)$. Muzaffar and Muhammad (2011) investigated the effect of inquiry laboratory teaching method on students' development of science process skills. The results indicated that inquiry laboratory teaching method is more effective in developing scientific process skill among secondary school science students of biology. Chebii, Wachanga and Kiboss (2012) investigated the effect of practical activities in mastery of selected process skills with experimenting being the focus. The findings indicated that the experimental group had mastered the skill better than the control group that was taught using the conventional methods. A study by Jack (2013) recommended that laboratories of secondary schools need to be well equipped to enable the teachers to adapt methods that will lead students to develop appropriate science process skills. A study conducted in Turkey by Berberoglu et al. (cited in Aydin, 2013) stressed that the method of designing and implementing laboratory experiments should be focused on development of higher level mental abilities (integrated science process skills). The study also indicated that to achieve this 
there is need to focus on open ended experiments and activities that improve creativity. A study by Sukarno et al. (2013) recommended that science process skill teaching can be done by development of teaching materials that are capable of directing teachers and students to practice science process skills. They also recommended the development of learning models that provide opportunities for teachers and students to co-develop science process skills.

In a study by Jeenthong, Ruenwongsa and Sriwattanarothai (2014) to promote secondary students' integrated science process skills, a pretest-posttest control group design was adopted for the study with two classrooms. The control group was taught by traditional lecture supplemented with readings while the experimental group experienced an intervention with the same content. The findings at the end of the study revealed that students experiencing an intervention gained a better understanding of integrated science process skills. The implication in these arguments is that science laboratories are the contexts where integrated science process skills are efficiently and progressively mastered. There exists a nexus between active student involvement in the learning process and the development of integrated science process skills. There is also need for consistent and multiple practical sessions to develop the integrated science process skills. This will give the learners tools to interpret what they observe and to design investigations to test their ideas.

\subsection{Justification for the Study}

CEMASTEA (2017) has observed that science process skills are part of a series of high order thinking skills, abilities and learning dispositions that students need to master in preparation for a dynamic and technological society. These have been generally referred to as the $21^{\text {st }}$ century skills. Mutua (2017) continues to emphasize that a heavy investment in Science, Technology, Engineering and Mathematics (STEM) subjects will not only develop the integrated science process skills but will also leverage the technological advances of tomorrow. Saat (2004) has noted that students acquire science process skills through the stages of recognition of scientific process, making habits and automation. In order to make the acquisition of this a meaningful reality at the end of secondary education course, there is need to monitor the mastery of integrated science process skills across all grades to ascertain the level of acquisition of the skills. According to Otieno (2017), there is a growing concern that a large proportion of women are not pursuing STEM related courses at the university which are disciplines for the development of integrated science process skills. According to the treatise by Otieno (2017), there are myths like the belief that science is a male domain and that science is inborn that contribute to women's low enrolment in STEM courses. Omondi (2017) avers that the enrollment of girls has increased in primary education in Kenya however, the relationship between males and females widens in higher education levels in favor of boys with regard to STEM subjects. This corroborates the need to investigate mastery of integrated science process 
skills from the perspective of gender. OECD (2009) has noted that the school environment is fundamental for schooling and instruction and affects students' learning outcomes. Martin et al. (2000) have noted that the relationship between student achievement and urbanicity of the school is expected to vary. Zeidan and Jayosi (2015) have made a case for the existence of different engagement levels in education among the students in village and city schools in Palestinia. They continue to note that this differential could be attributed to differences in motivational orientations to master science process skills. There is need to investigate mastery of integrated science process skill with school location as a variable within the context of Kenya.

\subsection{Problem and Purpose of the Study}

Mastery of integrated science process skills is significant to a developing country like Kenya. Despite the fact that many studies in science process skills have been done in the last three decades in general, few studies have been specific on mastery of integrated science process skills particularly in Kenya. One of the objectives of science education in Kenya is to teach science through the philosophy of discovery in which science process skills are an integral part. In recognition of this pedagogical philosophy, it is important to investigate the level of mastery of integrated science process skills which are relevant for the development of hypothetico-deductive reasoning and problem solving strategies. The purpose of this study is therefore to investigate the influence of grade level, gender, and school location in the mastery of integrated science process skills among co-educational secondary school students in Siaya County, Kenya.

\subsection{Objectives of the Study}

The study was guided by the following objectives:

- To determine the level of students' mastery of the integrated science process skills in grade $9,10,11$ and 12 .

- To determine the gender differences in students' mastery of integrated science process skills.

- To determine differences in students' mastery of integrated science process skills with regard to school location.

\subsection{Hypotheses of the Study}

The following hypotheses were tested:

- There is no statistically significant difference in the students' mastery of integrated science process skills among grade 9, 10, 11 and 12 .

- There is no statistically significant gender difference in the students' mastery of integrated science process skills among students in the schools.

- There is no statistically significant difference in students' mastery of integrated science process skills with regard to school location. 


\section{Methodology}

\subsection{Research Design}

The study adopted a causal-comparative design. Causal-comparative research does not involve manipulation of variables because their manifestations have occurred or they have fixed manipulative and uninfluenceable properties $(\mathrm{Mu}-$ genda \& Mugenda, 2003; Gall, Borg, \& Gall, 2003). Causal comparative research attempts to determine the cause and effect relationship for pre-existing differences in groups of individuals (Fraenkel \& Wallen, 2008). In this study, the pre-existing groups of students from a rural and an urban coeducational school were used in the pursuit of investigating and determining their mastery of integrated science process skills. The researcher therefore examined the effects of grade levels, gender and school location (independent variables) on mastery of integrated science process skills (controlling variables, defining operationally, formulating hypotheses, interpreting data, and experimenting) which are dependent variables. The effects in the groups had already occurred hence the independent variables were not manipulated. The groups were compared in order to investigate if there were significant differences in the mastery of integrated science process skills. The possible reasons for the differences in mastery of integrated science process skills were also given (Gall, Borg, \& Gall, 2003).

\subsection{Sampling Procedures and Sample Size}

Two schools that had the needed attributes were purposively sampled for the study. Purposive sampling technique is felicitous where attributes of the population are familiar or information rich with regard to the purpose of the study (Mugenda \& Mugenda, 2003; Gall, Borg, \& Gall, 2003; Fraenkel \& Wallen, 2008). School location has been aptly described by Okonkwo (Cited in Ugwanyi, 2015) as either rural or urban. Rural schools are located away from local government headquarters, and lack major amenities like health facilities, electricity and piped water. On the other hand, urban schools are located in areas within local government headquarters with key amenities like health centers, piped water and electricity. Sampling was purposively done to ensure that the schools with the characteristics of four grade levels, location and gender parity in enrolment are included in the study. One school was sampled from a rural location and another one from an urban location. The sample for this study was 429 students drawn from two co-educational public secondary schools in Siaya County. Table 1 gives the details of sample characteristics.

\subsection{Instrumentation}

The mastery of integrated science process skills was tested using Test of Integrated Science Process Skills (TISPS). This instrument was developed by Kazeni (2005) to test students' competence of integrated science process skills in high schools in the African context and consisted of 30 multiple choice items. Each item had four optional responses whereby only one response was correct and the 
other three options served as distracters. The instrument tested 5 categories of integrated science process skills. These are identifying and controlling variables, defining operationally, formulating hypotheses, experimenting and interpreting data. The original instrument had its internal consistency reliability coefficient developed using split half method that yielded an overall reliability of 0.81 . This instrument was administered to students in the rural and urban school and in the grades by the researcher in assistance by the science teachers in the sampled schools. The administration of the instrument took 60 minutes. The data collection process took place in second term of the Kenyan school calendar. The scales and their descriptions are shown in Table 2.

\subsection{Data Analysis}

The results from TISPS were scored using a key developed by the researcher. Each item in the instrument was worth one point. Hence the maximum mark

Table 1. Sample characteristics by grade, gender and school location.

\begin{tabular}{ccccc}
\hline Grade & Gender & Rural & Urban & Total \\
\hline 9 & Female & 34 & 25 & 59 \\
Male & Female & 29 & 29 & 58 \\
10 & Male & 37 & 25 & 62 \\
& Female & 19 & 27 & 49 \\
11 & Male & 23 & 26 & 52 \\
& Female & 21 & 31 & 53 \\
& Male & 25 & 28 & 50 \\
& Grand total & 214 & 24 & 429 \\
\hline
\end{tabular}

Table 2. Integrated science process skills and their descriptions.

\begin{tabular}{|c|c|}
\hline Integrated Science Process Skills & Description \\
\hline Controlling and identifying variables & $\begin{array}{l}\text { Identification of dependent, independent and controlled } \\
\text { variables. It includes variables that can affect an experi- } \\
\text { mental outcome. }\end{array}$ \\
\hline Defining operationally & $\begin{array}{c}\text { Stating how to measure a variable in an experiment. It in- } \\
\text { cludes identifying how variables are defined and selecting a } \\
\text { suitable operational definition. }\end{array}$ \\
\hline Formulating hypotheses & $\begin{array}{c}\text { Stating the expected outcome of an experiment. It includes } \\
\text { identifying a testable hypothesis. }\end{array}$ \\
\hline Experimenting & $\begin{array}{l}\text { Carrying out a test by carefully following procedures to } \\
\text { produce verifiable results. It includes selecting a suitable } \\
\text { design for an investigation to test a hypothesis. }\end{array}$ \\
\hline Interpreting data & $\begin{array}{l}\text { Organizing data, drawing conclusions from it, making sense } \\
\text { of data, identifying relationships between variables and } \\
\text { identifying a graph that represents data. }\end{array}$ \\
\hline
\end{tabular}

Adopted from Kazeni (2005) 
that a student could score was 30 marks. Data analysis was based on the students' score on the entire test. Descriptive statistics were used to summarize raw data according to the objectives of the study. Inferential statistics were used to analyze quantitative data and test the research hypotheses. The hypotheses were accepted at a significance level of $\alpha=0.05$. To determine the effect of grade level on the mastery of integrated science process skills, one way ANOVA was used. One way ANOVA is robust in comparing means between two or more groups and determines whether any of the means are statistically significantly different from each other. As an omnibus test statistic, it does not tell which particular groups are statistically different from each other. To cater for this shortcoming, post-hoc tests are done (Gall, Borg, \& Gall, 2003; Fraenkel \& Wallen, 2008). In this study, scheffe post-hoc test was carried out.

To determine the effect of gender and school location on the mastery of integrated science process skills, independent sample t-tests were carried out. The t-test is an inferential statistical procedure used to determine whether means of two samples are significantly different (Fraenkel \& Wallen, 2008). The dependent variable (mastery of integrated science process skills) was data in ratio scale, the groups were mutually exclusive, there were relationships between observations in each group and the independent variables (gender and school location) were two categorical independent groups. In this regard, independent sample t-test was appropriate for this analysis (Gall, Borg, \& Gall, 2003). Data analysis was conducted with the aid of Statistical Package for Social Sciences (SPSS) version 17.

\section{Results}

\subsection{Grade level Differences on Mastery of Integrated Science Process Skills}

To establish whether grade level had an influence on the students' mastery of integrated science process skills, descriptive statistics are first presented followed by analysis of one way ANOVA and post-hoc comparisons. Table 3 shows the descriptive statistics.

Table 3 shows that there is a progressive increase in the students' mastery of integrated science process skills from grade 9 to grade 12 as depicted by the means. It also shows that the combined percentage mean for the entire sample was above the midpoint of $15(57.02 \%)$. This indicates a moderate mastery of integrated science process skills. On the other hand, the mastery of grade 9 students was below the midpoint of 15 (46.64\%) indicating a poor mastery of integrated science process skills. The mastery of students in grade 12 is the highest (65.51\%) of the four grades indicating the best of the four grades. It was necessary to carry out a one-way ANOVA test to determine whether the differences between the grade levels were statistically significant. Table 4 shows the output of the test.

Table 4 shows that there was a statistically significant difference between the 
Table 3. Descriptive statistics by grade level for mastery of integrated science process skills.

\begin{tabular}{ccccc}
\hline Grade-level & N & Mean & Percentage mean & Standard deviation \\
\hline 9 & 117 & 13.9915 & 46.64 & 3.4126 \\
10 & 108 & 16.7130 & 55.71 & 3.1087 \\
11 & 101 & 18.6796 & 62.27 & 4.5937 \\
12 & 103 & 19.5347 & 65.51 & 4.0879 \\
Total & 429 & 17.1070 & 57.02 & 4.3802 \\
\hline
\end{tabular}

Table 4. ANOVA output for mastery of integrated science process skills by grade.

\begin{tabular}{ccccccc}
\hline Source & Sum of squares & df & Mean squares & $F$ & $p$-value & Eta $^{2}$ \\
\hline Between groups & 2002.418 & 3 & 667.473 & 45.690 & 0.000 & 0.243 \\
Within groups & 6208.649 & 425 & 14.609 & & & \\
Total & 8211.068 & 428 & & & & \\
\hline
\end{tabular}

$p<0.05$.

means $F(3,425)=45.690, p<0.05$. The effect size indicates that $24.3 \%$ of the variance in the dependent variable was caused by the independent variable. It was necessary to carry out further tests on the combinations of means to find out where the differences occurred (post-hoc tests). Table 5 shows the results of scheffe post-hoc comparisons.

Table 5 shows that scores of pairs of grade 9 and 10, grade 9 and 11, grade 9 and 12,10 and 11,10 and 12 and grade 11 and 12 were significantly different at an alpha level of 0.05 . Overall, there was a statistically significant difference between the groups in mastery of integrated science process skills between all the grades from 9 to 12 . The hypothesis that 'There is no statistically significant difference in the students' mastery of integrated science process skills among grade $9,10,11$ and 12 ' was therefore rejected.

\subsection{Gender Differences in Mastery of Integrated Science Process Skills}

To establish whether gender had an influence on the mastery of integrated science process skills, descriptive statistics are first presented followed by independent sample t-test analysis. Table 6 shows the descriptive statistics.

Table 6 shows that the mean score of boys was higher than the mean score of girls in the performance of the integrated science process skills test. Indicating that boys' mastery of integrated science process skills was higher than that of girls'. However it was necessary to determine whether these differences were statistically significant. Table 7 shows the Levene's test for equality of variances and t-test for equality of means.

Table 7 shows that Levene's tests did not produce significant results hence t-tests are based on variances assumed. The table indicates that boys' mastery of 
Table 5. Scheffe post-hoc comparisons.

\begin{tabular}{ccccc}
\hline (I)Grade & (J)Grade & Mean Difference (I-J) & Standard Error & $p$-value \\
\hline 9 & 10 & $-2.7215^{*}$ & .5100 & 0.000 \\
& 11 & $-4.6881^{*}$ & .5164 & 0.000 \\
\multirow{2}{*}{10} & 12 & $-5.5432^{*}$ & .5191 & 0.000 \\
& 9 & $2.7215^{*}$ & .5100 & 0.000 \\
& 11 & $-1.9667^{*}$ & .5264 & 0.000 \\
11 & 12 & $-2.8217^{*}$ & .5290 & 0.003 \\
& 9 & $4.6881^{*}$ & .5191 & 0.000 \\
& 10 & $1.9667^{*}$ & .5264 & 0.000 \\
12 & 12 & $-0.8550^{*}$ & .5352 & 0.004 \\
& 9 & $5.5432^{*}$ & .5191 & 0.000 \\
& 10 & $2.8217^{*}$ & .5290 & 0.003 \\
& 11 & $0.8550^{*}$ & .5352 & 0.004 \\
\hline
\end{tabular}

${ }^{\star} p<0.05$.

Table 6. Descriptive statistics by gender.

\begin{tabular}{ccccc}
\hline Gender & N & Mean & Standard Deviation & Standard Error Mean \\
\hline Boys & 206 & 17.7670 & 4.3699 & .3044 \\
Girls & 223 & 16.4978 & 4.3099 & .2886 \\
\hline
\end{tabular}

Table 7. Levene's test and independent sample t-test for gender.

\begin{tabular}{|c|c|c|c|c|c|c|c|c|}
\hline & \multicolumn{8}{|c|}{ Group $1=$ Boys, Group $2=$ Girls } \\
\hline & \multicolumn{2}{|c|}{$\begin{array}{l}\text { Levene's test for } \\
\text { equality of variances }\end{array}$} & \multicolumn{6}{|c|}{$\mathrm{t}$-test for equality of means } \\
\hline & $F$ & Sig & $t$ & df & $p$-value & MD & SED & ES \\
\hline $\begin{array}{l}\text { Equal variances } \\
\text { assumed }\end{array}$ & 0.073 & .787 & 3.027 & 427 & 0.003 & 1.2692 & .4193 & 0.292 \\
\hline $\begin{array}{l}\text { Equal variances } \\
\text { not assumed }\end{array}$ & & & 3.025 & 423.31 & 0.003 & 1.2692 & .4195 & \\
\hline
\end{tabular}

$p<0.05, \mathrm{MD}=$ Mean Difference, $\mathrm{SED}=$ Standard Error Mean, Es $=$ Effect Size.

integrated science process skills is higher than the girls' mastery of the same as depicted by the $\mathrm{t}$-value and mean difference. At the same time, there existed a statistically significant difference between boys and girls in favor of boys, $t$ (427) $=3.027, p<0.05$. The effect size indicates that $29.2 \%$ of the variance in the dependent variable was caused by the independent variable. The hypothesis that 'There is no statistically significant gender difference in the students' mastery of integrated science process skills among students in the schools' was rejected.

\subsection{School Location Differences in Mastery of Integrated Science Process Skills}

To establish whether school location had an influence on the students' mastery 
of integrated science process skills, descriptive statistics are first presented followed by independent sample t-test analysis. Table 8 shows the descriptive statistics.

Table 8 shows that the mean score of the urban school students was higher than the mean score of the rural school students in the performance of the integrated science process skills test. Indicating that urban school students' mastery of integrated science process skills was higher than that of the rural school students'. However it was necessary to determine whether these differences were statistically significant. Table 9 shows the Levene's test for equality of variances and $\mathrm{t}$-test for equality of means.

Table 9 shows that Levene's tests did not produce significant results hence $\mathrm{t}$-tests are based on variances assumed. The table indicates that the urban school students' mastery of integrated science process skills is higher than that of the rural school students' mastery of the same as depicted by the negative t-value and the negative mean difference. At the same time, there existed a statistically significant difference between the rural school students' and the urban school students' in favor of the urban school students, $t(427)=-9.587, p<0.05$. The effect size indicates that $92 \%$ of the variance in the dependent variable was caused by the independent variable. The hypothesis that 'There is no statistically significant difference in students' mastery of integrated science process skills among rural and urban schools's students was rejected.

\section{Discussions}

From the data analysis on the "grade level differences", the findings indicated that there was a progressive increase in the mastery of integrated science process skills from grade 9 to grade 12. There was also a moderate mastery of integrated science process skills of the entire sample. There was also the existence of statistically significant grade level differences between any pair of grade levels. These

Table 8. Descriptive statistics by location.

\begin{tabular}{ccccc}
\hline School location & N & Mean & Standard Deviation & Standard Error Mean \\
\hline Rural & 214 & 15.2617 & 3.9082 & .2672 \\
Urban & 215 & 18.9442 & 4.0460 & .2759 \\
\hline
\end{tabular}

Table 9. Levene's test and Independent sample t-test for location.

\begin{tabular}{|c|c|c|c|c|c|c|c|c|}
\hline & \multicolumn{8}{|c|}{ Group $1=$ Rural, Group $2=$ Urban } \\
\hline & \multicolumn{2}{|c|}{$\begin{array}{c}\text { Levene's test for } \\
\text { equality of variances }\end{array}$} & \multicolumn{6}{|c|}{ t-test for equality of means } \\
\hline & $F$ & Sig & $t$ & df & $p$-value & MD & SED & ES \\
\hline $\begin{array}{c}\text { Equal variances } \\
\text { assumed }\end{array}$ & 0.626 & .429 & -9.587 & 427 & 0.000 & -3.6825 & .38411 & -.92 \\
\hline $\begin{array}{c}\text { Equal variances } \\
\text { not assumed }\end{array}$ & & & -9.588 & 426.626 & 0.000 & -3.6825 & .38408 & \\
\hline
\end{tabular}

$p<0.05, \mathrm{MD}=$ Mean Difference, $\mathrm{SED}=$ Standard Error Mean, ES $=$ Effect size. 
findings are more or less the similar to different studies. Beaumont-Walters and Soyibo (2001) found significant grade level differences between grade 9 and 10 in favor of the $10^{\text {th }}$ grade. Jusoh (cited in Tek \& Ruthven, 2005) found significant grade level differences between form 2 and 4 in mastery of integrated science process skills. Eng et al. (2015) found significant grade level differences between year 4 and 6 in favor of year 6 in mastery of basic science process skills among primary school students. It appears that students in the higher grade levels have a better mastery of integrated science process skills than the students in lower grades. This implies that as the learners progress through the grades, they acquire a cognitive maturity that enables them to master the integrated science process skills and vice versa. This finding confirms the conclusion by Saat (2004) who opined that acquisition of science process skills occurs through the stages. Exposure to more experimental settings as the grade level advances could also be a contributor to the increasing trend in the mastery of integrated science process skills as the grade levels increase. The present study was unique from the rest in the sense that it focused on four grade levels at the secondary school level in Kenya.

From the data analysis on the "gender differences", the findings indicated the existence of gender differences in favor of boys in the mastery of integrated science process skills. This finding contradicts certain findings. Jusoh (cited in Tek \& Ruthven, 2005) found statistically significant differences in favor of girls with regard to hypothesizing, identifying variables, evaluating data and graph. Zeidan and Jayosi (2015) found gender differences in favor of girls with regard to knowledge of both basic and integrated science process skills. Ong et al. (2012) found that the female students achieved a markedly higher mean percentage score in the overall science process skill than the male students. Abungu, Okere and Wachanga (2014) found gender differences in favor of boys in an achievement test after exposure to a science process skill teaching strategy in Chemistry. Beaumont-Walters and Soyibo (2001) found no gender differences in mastery of integrated science process skills. Kiu Ling Feng (cited in Ong et al., 2012) found no statistically significant gender differences in mastery of integrated science process skills. Eng et al. (2015) found no gender differences in the mastery of basic science process skills among primary school students. Ugwanyi (2015) found no significant gender differences in acquisition of a mixture of basic and integrated science process skills in practical Chemistry. The gender differences in favor of boys in this study can be attributed to gender biased pedagogic practices that could be prevailing in learning environments. Despite the fact that the Kenyan government through the ministry of education has tried to aggressively campaign for reduction of gender gaps in the classroom pedagogic practices, it appears this is yet to be adopted and adapted in some parts of the country.

From the data analysis on the "school location differences" the findings indicated the existence of school location differences in favor of the urban school 
students in the mastery of integrated science process skills. This finding contradicts some findings. Zeidan and Jayosi (2015) found statistically significant differences between village schools and city schools in favor of the village schools. Beaumont-Walters and Soyibo (2001) found no statistically significant relationship between performance in integrated science process skills and school location. Ong et al. (2012) found no statistically significant differences in integrated science process skills acquisition between rural and interior (urban) students. Jack (2013) also found no statistically significant differences in terms of location on the mastery of both categories of science process skills. This study is in concurrence with Eng et al. (2015) that found school location differences in favor of the urban schools. However the study was done among primary school students and focused on basic science process skills. It also concurs with Ugwanyi (2015) who found statistically significant school location differences between urban and rural schools in favor of urban school in Chemistry practical science process skills. With regard to the present findings, a confluence of factors could have contributed to the differences. Murunga, Kilaha and Wanyonyi (2013) found out that in Kenya there is an imbalance in the distribution of secondary school teachers with most of the teachers preferring urban schools to the rural ones. In this study, this is likely to have been compounded by the quality of the training of the teachers who teach science subjects and the poor endowment of rural schools with facilities that can be used to teach science through the process approach.

\section{Conclusions and Implications}

Based on the findings from this study, the following conclusions are made:

- As the grade level advances, the students' mastery of integrated science process skills increases.

- Boys have a higher mastery of integrated science process skills than girls.

- The students in the urban school have a higher mastery of integrated science process skills than the students in the rural school.

The study has following implications for practice and research:

- There is need to constantly monitor the mastery of integrated science process skills across the grades to ensure a continuous development and mastery of these skills. This can be done through exposure of learners to the required experimental settings. Implicit in the findings is also the need to expose the learners to situations where they master the integrated science process skills from simple to complex.

- In the light of gender gaps in achievement and enrollment, there is need to make deliberate efforts to adopt pedagogic practices in the classroom that are gender inclusive to get more girls developing integrated science process skills which are precursors to creativity, critical thinking and problem solving that are needed in the $21^{\text {st }}$ century.

- There is need to determine unequivocally from the perspective of research in 
Kenya the reasons for the school location differences in the mastery of integrated science process skills. The study needs replication to cover a wider geographical area with more variables under investigation.

\section{Limitations}

The study has the following limitations:

1) Purposive sampling was used in the study. This reduces the generalizability of the findings to the entire county.

2) The study was limited to coeducational schools in the county.

\section{References}

Abungu, H. E. O., Okere, M. I. O., \& Wachanga, S. W. (2014). Effect of Science Process Skills Teaching Strategy on Boys' and Girls' Achievement in Chemistry in Nyando District, Kenya. Journal of Education and Practice, 5, 42-48.

Aydin, A. (2013). Representation of Science Process Skills in Chemistry Curricula for Grades 10, 11, 12, Turkey. International Journal of Education and Practice, 1, 51-63. https://doi.org/10.18488/journal.61/2013.1.5/61.5.51.63

Aziz, S. M., \& Zain, A. N. M. (2010). The Inclusion of Science Process Skills in Yemeni Secondary School Physics Text Books. European Journal of Physics Education, 1, 44-50.

Beaumont-Walters, Y., \& Soyibo, K. (2001). An Analysis of High School Students' Performance on Five Integrated Science Process Skills. Research in Science \& Technological Education, 19, 133-145. https://doi.org/10.1080/02635140120087687

Brotherton, P. N., \& Preece, P. F. W. (1995). Science Process Skills: Their Nature and Interrelationships. Research in Science and Technological Education, 13, 5-11. https://doi.org/10.1080/0263514950130101

Burns, J. C., Okey, J. R., \& Wise, K. C. (1985). Development of an Integrated Process Skill Test: TIPS II. Journal of Research in Science Teaching, 22, 169-177. https://doi.org/10.1002/tea.3660220208

CEMASTEA (2017). Training Module for Secondary School Teachers on Inquiry Based Learning in Mathematics and Science. CEMASTEA: Nairobi.

Chebii, R., Wachanga, S., \& Kiboss, K. (2012). Effects of Science Process Skills Mastery Learning Approach on Students' Acquisition of Selected Chemistry Practical Skills in School. Creative Education, 3, 1291-1296. https://doi.org/10.4236/ce.2012.38188

Eng, T. O., Puspa, R., Kenneth, R. S. M. S., Nick, A. N. Y., \& Siti, E. M. (2015). Acquisition of Basic Science Process Skills among Malaysian Primary Students. Research in Education, 94, 88-101. https://doi.org/10.7227/RIE.0021

Feyzioglu, B. (2009). An Investigation of the Relationship between Science Process Skills with Efficient Laboratory Use and Science Achievement in Chemistry Education. Journal of Turkish Science Education, 6, 114-132.

Fraenkel, J. R., \& Wallen, N. E. (2008). How to Design and Evaluate Research in Education (7th ed.). New York: McGraw-Hill.

Gall, M. D., Borg, W. R., \& Gall, J. P. (2003). Educational Research: An Introduction (7th ed.). New York: Longman, Inc.

Jack. G. U. (2013). The Influence of Identified Student and School Variables on Students' Process Skills Acquisition. Journal of Education and Practice, 4, 16-22. 
Jeenthong, T., Ruenwongsa, P., \& Sriwattanarothai, N. (2014). Promoting Integrated Science Process Skills through Betta-Live Science Laboratory. Procedia Social and Behavioral sciences, 116, 3292-3296. https://doi.org/10.1016/j.sbspro.2014.01.750

Kazeni, M. M. M. (2005). Development and Validation of a Test of Integrated Science Process Skills for the Further Education and Training of Learners. MS.C. Thesis, Pretoria: University of Pretoria.

Keil, C., Haney, J., \& Zoffel, J. (2009). Improvements in Student Achievement and Science Process Skills Using Environmental Health Science Problem Based Learning Curricula. Electronic Journal of Science Education, 13, 1-17.

Martin, M. O., Mullis, I. V. S., Gregory, K. D., Hoyle, C., \& Shen, C. (2000). Effective Schools in Science and Mathematics. Boston: TIMSS International Study Centre, Boston College. http://www.pirls.bc.edu/timss1995i/TIMSSPDF/T95_EffSchool.pdf

Mugenda, O., \& Mugenda, A. (2003). Research Methods Quantitative and Qualitative Approaches. Nairobi: Acts Press.

Murunga, F., Kilaha, K., \& Wanyonyi, D. (2013). Emerging Issues in Secondary Education in Kenya. International Journal of Advanced Research, 1, 231-240.

Mutlu, M., \& Temiz, B. K. (2013). Science Process Skills of Students Having Field Dependent and Field Independent Cognitive Styles. Educational Research Reviews, 8, 766-776.

Mutua, C. (2017). Science, Technology, Engineering and Mathematics (STEM) Is the Future. Nairobi: The Standard Media Group.

Muzaffar, K., \& Muhammad, Z. I. (2011). Effect of Inquiry Lab Teaching Method on the Development of Scientific Skills through the Teaching of Biology in Pakistan. Language in India, 11, 169-178.

Necati, H. (2013). Influence of Hands on Physics Experiments on Scientific Process Skills According to Prospective Teachers' Experiences. European Journal of Physics Education, 4, 1-9.

Nwosu, A. A., \& Okeke, E. A. C. (1995). The Effect of Teacher Sensitization of Students Acquisition of Science Process Skills. Journal of Science Teachers' Association of Nigeria (STAN), 30, 39-45.

OECD (2009). Creating Effective Teaching and Learning Environments: First Results from TALIS. Paris: OECD. https://doi.org/10.1787/9789264068780-en

Omondi, D. (2017). Girls Shy Away from STEM Courses. Nairobi: The Standard Media Group.

Ong, E. T., Wong, Y. T., Sopia, M. Y., Sadia, B., Asmayati, Y., \& Zahd, M. S. (2012). Malaysian-Based Science Process Skill Inventory Development, Validation and Utilization. Current Research in Malaysia, 1, 125-149.

Opateye, J. A. (2012). Developing and Assessing Science and Technology Process Skills (STPSs) in Nigeria Universal Basic Education Environment. Journal of Educational and Social Research, 2, 34-42.

Otieno, J. (2017). Factors Keeping Women Away from Science and Technology Courses. Nairobi: The Standard Media Group.

Ozgelen, S. (2012). Scientists' Science Process Skills within a Cognitive Domain Framework. Eurasia Journal of Mathematics, Science and Technology Education, 8, 283-292.

Padilla, M. J. (1990). The Science Process Skills. Research Matters to the Science Teacher. ERIC Document Reproduction Service No ED266961.

Rambuda, A. M., \& Fraser, W. J. (2004). Perceptions of Teachers of the Application of 
Science Process Skills in Teaching Geography in Secondary Schools in the Free State Province. South African Journal of Education, 24, 10-17.

Saat, R. M. (2004). The Acquisition of Integrated Science Process Skills in a Web-Based Learning Environment. Research in Science and Technology Education, 22, 23-40. https://doi.org/10.1080/0263514042000187520

Sukarno, Permanasari, A., \& Idah, H. (2013). The Profile of Science Process Skills Student at Secondary High School (Case Study in Jambi). International Journal of Scientific Engineering and Research, 1, 79-83.

Tek, O. E., \& Ruthven, K. (2005). Acquisition of Science Process Skills amongst form 3 Students in Malaysian Smart and Mainstream Schools. Journal of Science and Mathematics Education in S.E Asia, 28, 103-124.

Ugwanyi, A. A. (2015). Science Process Skills Acquired by Senior Secondary School Students in Enugu Educational Zone. Master's Thesis, Nsukka: University of Nigeria.

Zeidan, A. H., \& Jayosi, M. R. (2015). Science Process Skills and Attitudes towards Science among Palestinian Secondary School Students. World Journal of Education, 5, 13-24.

\section{Submit or recommend next manuscript to SCIRP and we will provide best service for you:}

Accepting pre-submission inquiries through Email, Facebook, LinkedIn, Twitter, etc. A wide selection of journals (inclusive of 9 subjects, more than 200 journals) Providing 24-hour high-quality service User-friendly online submission system Fair and swift peer-review system Efficient typesetting and proofreading procedure Display of the result of downloads and visits, as well as the number of cited articles Maximum dissemination of your research work

Submit your manuscript at: http://papersubmission.scirp.org/

Or contact ce@scirp.org 